\title{
Spinal cord stimulation in peripheral vascular disease
}

\author{
RC TALLIS,* LS ILLIS, EM SEDGWICK, C HARDWIDGE, JS GARFIELD \\ From the Wessex Neurological Centre and the Southampton General Hospital, Southampton, UK
}

SUMMARY The results of ten patients with severe, intractable symptoms of arterial disease receiving spinal cord stimulation are reported. Six out of ten patients showed clinical improvement. Three of five patients with severe rest pain obtained complete or very marked relief and one of two patients with moderate rest pain in the legs obtained complete relief. The mean claudication distance in the ten patients increased from 65 to 212 metres during epidural stimulation of the spinal cord. Exercise tolerance as measured on a bicycle ergometer increased by $61 \%$. These changes were associated with small increases in cutaneous and muscle blood flow. In those patients who responded clinically, the improvements seen were maintained as long as spinal cord stimulation was continued. There was no clinical response to transcutaneous (placebo) stimulation and four patients did not respond in any way to spinal cord stimulation. The improvements seen are unlikely to be due to either the natural history of the disease or to a placebo effect. The effect is probably due to antidromic stimulation of the central processes of the first order sensory neurons. It is suggested on the basis of animal studies that this effect may be mediated by release of prostaglandins as well as indirectly via pain relief.

Spinal cord stimulation was first introduced into clinical practice for the treatment of intractable pain. ${ }^{1}$ Since Cook \& Weinstein ${ }^{2}$ reported its therapeutic benefit in multiple sclerosis, it has also been used in the rehabilitation of patients with chronic neurological disease. The employment of epidural electrodes ${ }^{3}$ makes spinal cord stimulation a relatively minor procedure since the electrodes can be introduced via an epidural needle. Most workers are agreed that the main benefits of spinal cord stimulation are in bladder function ${ }^{4-6}$ and it is these changes that have been most carefully documented.

Less attention has been paid to other influences that spinal cord stimulation may have upon the autonomic nervous system. The fact that patients receiving spinal cord stimulation usually describe a sensation of warmth, especially in the lower limbs, suggested that spinal cord stimulation may alter blood flow in the skin. Patients with dependent discolouration due to stagnant hypoxia associated with poor peripheral circulation in multiple sclerosis show improvement in the colour of dependent limbs. Friedman ${ }^{7}$ noted a thermographically detect-

\footnotetext{
${ }^{*}$ Present address and address for reprint requests: Dr RC Tallis, Senior Lecturer in Geriatric Medicine, Royal Liverpool Hospital, Liverpool, L69 3BX, UK
}

Received 25 November 1982

Accepted 5 January 1983 able increase in blood flow in the region of analgesia during spinal cord stimulation for pain. Cook et $a^{8}$ described pain relief and healing of ulcers in nine patients with vascular insufficiency in the limbs which in many cases had failed to respond to conventional therapy. These changes could be repeatedly cycled by starting or stopping stimulation. However, few measurements have been made of blood flow during spinal cord stimulation. More detailed studies have been done in the case of transcutaneous stimulation with conflicting results being reported. $^{9-12}$

In view of these observations, and our own experience of a patient with multiple sclerosis and arteriographically demonstrated peripheral vascular insufficiency who reported decreased claudication pain during the period of spinal cord stimulation, despite increased mobility, we studied the effects of spinal cord stimulation upon cutaneous blood flow in the lower limbs of patients receiving this treatment for chronic neurological disease.

We were able to demonstrate an increase in cutaneous blood flow in these patients ${ }^{13}$ and therefore felt justified in embarking upon a trial of spinal cord stimulation in peripheral vascular insufficiency. The purpose of this paper is to present preliminary observations on 10 such patients who received epidural spinal cord stimulation. In seven of these patients this was preceded by a period of trans- 
cutaneous stimulation which we believe acts only as a placebo in this context. In an eighth patient transcutaneous stimulation immediately followed spinal cord stimulation. Two patients received spinal cord stimulation alone.

\section{Methods}

PATIENTS:

All patients were referred from the Department of Vascular Surgery at the Royal South Hampshire Hospital where they had been under the care of either Mr J Webster, or Mr AD Chant. In all cases the diagnosis was clear and arteriographically proven, symptoms were severe and disabling and had not responded to conventional surgical and medical therapy. Clinical details of the patients studied are given in Table 1. All patients had been instructed to give up smoking at the onset of their illness and four had complied with this absolutely. Six had been unable to give up smoking entirely but their smoking pattern had been stable for many months prior to the period of stimulation and remained constant throughout this. In particular, the timing of cigarettes in relation to investigations was constant throughout the period of study.

\section{METHODS OF ASSESSMENT}

Claudication distance: Claudication distance was measured several times prior to and during each period of stimulation at fixed times of day over a given course at a fixed walking speed. In cases 9 and 10 claudication distance was assessed by means of a treadmill set at $2 \mathrm{~km}$ per hour. Severe rest pain prevented complete assessment of case 7 .

Exercise tolerance: Exercise tolerance was measured on a bicycle ergometer, the patient being required to maintain 100 watts. The time to the point at which this was no

Table 1 Patients with peripheral vascular disease receiving spinal cord stimulation

\begin{tabular}{|c|c|c|c|c|c|c|c|}
\hline Case & Age & $\operatorname{Sex}$ & $\begin{array}{l}\text { Duration of } \\
\text { Ischaemic } \\
\text { symptoms (yr) }\end{array}$ & $\begin{array}{l}\text { Symptoms at time of } \\
\text { spinal cord } \\
\text { stimulation }\end{array}$ & $\begin{array}{l}\text { Period for which } \\
\text { symptoms had been } \\
\text { stable prior to } \\
\text { stimulation }\end{array}$ & $\begin{array}{l}\text { Result of last } \\
\text { angiogram }\end{array}$ & Previous treatment \\
\hline 1 & 67 & $\mathbf{M}$ & 2 & $\begin{array}{l}\text { Rest pain } \\
\text { Claudication Ulcer }\end{array}$ & 5 months & $\begin{array}{l}\text { Diffuse atheroma } \\
\text { with stenosis in } \\
\text { femoral tree }\end{array}$ & $\begin{array}{l}\text { Lumbar sympathectomy } \\
\text { Diabetic controlled on } \\
\text { insulin }\end{array}$ \\
\hline 2 & 69 & $\mathbf{M}$ & 2 & Claudication & 1 year & Diffuse atheroma & $\begin{array}{l}\text { Diffuse disease: surgery } \\
\text { not appropriate }\end{array}$ \\
\hline 3 & 69 & $\mathbf{M}$ & 2 & $\begin{array}{l}\text { Rest pain } \\
\text { Claudication }\end{array}$ & 6 months & $\begin{array}{l}\text { Superficial femoral } \\
\text { arteries blocked }\end{array}$ & $\begin{array}{l}\text { Left femoro-popliteal } \\
\text { bypass } \\
\text { Right femoro-popliteal } \\
\text { bypass }\end{array}$ \\
\hline 4 & 34 & $\mathbf{F}$ & 10 & $\begin{array}{l}\text { Claudication } \\
\text { Rest pain } \\
\text { Pain right hand }\end{array}$ & 9 months & $\begin{array}{l}\text { Severe generalised } \\
\text { Buerger's disease }\end{array}$ & $\begin{array}{l}\text { Left lumbar } \\
\text { sympathectomy } \\
\text { Right lumbar } \\
\text { sympathectomy } \\
\text { Right Gritti-Stokes } \\
\text { amputation } \\
\text { Right cervical } \\
\text { sympathectomy }\end{array}$ \\
\hline 5 & 77 & $\mathbf{M}$ & 11 & $\begin{array}{l}\text { Claudication } \\
\text { Intermittent rest pain } \\
\text { Severe nocturnal } \\
\text { rest pain }\end{array}$ & 3 months & $\begin{array}{l}\text { Atheroma. Stenosis } \\
\text { left common iliac }\end{array}$ & $\begin{array}{l}\text { Bilateral lumbar } \\
\text { sympathectomies }\end{array}$ \\
\hline 6 & 71 & $\mathbf{M}$ & 10 & Claudication & 18 months & $\begin{array}{l}\text { Occluded left femoro- } \\
\text { popliteal by-pass } \\
\text { Atheromatous left } \\
\text { superficial femoral } \\
\text { with block. Occluded } \\
\text { popliteal. }\end{array}$ & $\begin{array}{l}\text { Right femoro- } \\
\text { popliteal by-pass } \\
\text { Left femoro- } \\
\text { popliteal by-pass }\end{array}$ \\
\hline 7 & 62 & $\mathbf{M}$ & $31 / 2$ & $\begin{array}{l}\text { Ulcer } \\
\text { Rest pain } \\
\text { Claudication }\end{array}$ & 3 months & $\begin{array}{l}\text { Atheroma. Occlusion } \\
\text { of superficial } \\
\text { femorals. }\end{array}$ & $\begin{array}{l}\text { Left femoro- } \\
\text { popliteal by-pass }\end{array}$ \\
\hline 8 & 60 & $\mathbf{M}$ & 11 & $\begin{array}{l}\text { Claudication } \\
\text { Nocturnal rest } \\
\text { pain }\end{array}$ & 5 months & $\begin{array}{l}\text { Occlusion left iliac } \\
\text { and superficial } \\
\text { femorals. }\end{array}$ & $\begin{array}{l}\text { Aorto-iliac } \\
\text { endarterectomy } \\
\text { Right femoro- } \\
\text { popliteal by-pass } \\
\text { External iliac to } \\
\text { external iliac cross- } \\
\text { over graft }\end{array}$ \\
\hline 9 & 61 & $\mathbf{M}$ & 13 & Claudication & $3-4$ years & $\begin{array}{l}\text { Narrowing of aorta } \\
\text { and iliac vessels. } \\
\text { Blocked right } \\
\text { superficial femoral } \\
\text { and popliteal artery. }\end{array}$ & $\begin{array}{l}\text { Right sapheno- } \\
\text { femoral } \\
\text { endarterectomy } \\
\text { Right femoro-popliteal } \\
\text { by-pass }\end{array}$ \\
\hline 10 & 57 & $\mathbf{M}$ & 7 & Claudication & 4 months & $\begin{array}{l}\text { Iliacs blocked. No } \\
\text { flow in left } \\
\text { popliteal. }\end{array}$ & $\begin{array}{l}\text { Aortic onlay graft. } \\
\text { Thrombectomy from } \\
\text { aortic graft }\end{array}$ \\
\hline
\end{tabular}


longer possible was recorded. A mean of three measurements was obtained on at least two occasions prior to stimulation and during each period of stimulation. The severity of rest pain prevented this from being measured in cases 1 and 7.

Cutaneous blood flow: Cutaneous blood flow after a half hour period of rest with the patient supine was measured in eight patients by clearance of injected xenon 133 dissolved in saline. ${ }^{14}$ Sites just below the head of the fibula and on the dorsum of the feet were used. In two patients (cases 7 and 10) rest pain made it impossible to make measurements in both legs so the leg more affected by symptoms was examined. Case 4 had had a mid-thigh amputation of the right leg.

Muscle blood flow: This was measured by xenon clearance, the blood flow being recorded in the calf muscles at rest and during exercise with a specially designed standard calf exerciser. Only three out of the 10 patients were able to maintain exercise for a sufficiently long period for a meaningful clearance curve to be obtained (cases 2, 3 and 4). Resting muscle blood flow was recorded in two further patients (cases 6 and 10).

After selection for the trial the patients underwent full assessment. This was repeated on admission to hospital and the following day electrodes were put in place. Seven of the patients had ten days of transcutaneous stimulation and the assessment was repeated. Electrodes were then changed over from transcutaneous stimulation to spinal cord stimulation and after a further ten days of stimulation the assessment was again repeated. In one patient spinal cord stimulation immediately preceded transcutaneous stimulation and in two patients spinal cord stimulation alone was given because they were in a clinically critical state and a ten day delay before spinal cord stimulation could not be ethically justified.

\section{PROCEDURE:}

Epidural spinal cord stimulation: The method of inserting epidural electrodes through an epidural needle for spinal cord stimulation has been described.4 ${ }^{45}$ The electrodes were positioned so that the patient experienced a pleasant tingling sensation extending symmetrically down into the legs when the stimulator was switched on. The stimulator delivers a continuous train of square wave pulses of $200 \mu \mathrm{s}$ duration at approximately $8 \mathrm{~mA}^{16}$ and at a frequency of about $33 \mathrm{~Hz}$ and was switched on continuously during the period of the trial.

Transcutaneous Stimulation: In eight patients the response to spinal cord stimulation was compared with that to a comparable period of transcutaneous stimulation delivered by means of surface slectrodes placed over the lumbar spine. It was intended that transcutaneous stimulation should act as a placebo. No indication was given to the patient as to which electrodes would be expected to produce an effect. Nevertheless, it was not possible to carry out a completely blind trial because different stimulator sensations are associated with surface electrodes (local tingling) and epidural electrodes (paraesthesiae and warmth throughout the lower limbs).

\section{Results}

CLINICAL RESPONSE TO EPIDURAL SPINAL CORD STIMULATION (table 2)

Of five patients with severe rest pain occurring night and day, three obtained complete or very marked relief and two obtained no relief. One of two patients with moderate rest pain in the leg obtained complete relief but rest pain persisted in her hands.

Table 2 Clinical response to spinal cord stimulation (SCS)

\begin{tabular}{|c|c|c|c|c|c|c|c|c|}
\hline \multirow[t]{2}{*}{ Patient } & \multicolumn{2}{|c|}{ Rest pain* } & \multicolumn{2}{|c|}{ Claudication distance } & \multirow[t]{2}{*}{ Other clinical changes } & \multicolumn{3}{|c|}{ Subsequent progress } \\
\hline & $\begin{array}{l}\text { Before } \\
\text { SCS }\end{array}$ & $S C S$ & $\begin{array}{l}\text { Before } \\
\text { SCS }\end{array}$ & $S C S$ & & $\begin{array}{l}\text { Permanent } I \\
\text { stimulation }\end{array}$ & $\begin{array}{l}\text { Follow-up } \\
\text { (months) }\end{array}$ & Subsequent course \\
\hline 1. & +++ & - & $58 \pm 5$ & $\begin{array}{l}320 \pm 80 \\
\text { Improved }\end{array}$ & $\begin{array}{l}\text { Indolent ulcer healed. } \\
\text { Improved colour of foot }\end{array}$ & YES & 26 & $\begin{array}{l}\text { Improvement maintained except } \\
\text { sporadic rest pain }\end{array}$ \\
\hline 2. & - & - & $120 \pm 21$ & $\begin{array}{l}372 \pm 92 \\
\text { Improved }\end{array}$ & Improved colour of foot & YES & 15 & $\begin{array}{l}\text { Further improvement. Claudicatio } \\
\text { at } 900 \text { metres }\end{array}$ \\
\hline 3. & +++ & + & $16 \pm 3$ & $\begin{array}{l}366 \pm 208 \\
\text { Improved }\end{array}$ & $\begin{array}{l}\text { Improved colour of foot. } \\
\text { Reported restoration of } \\
\text { sweating in feet }\end{array}$ & YES & 12 & $\begin{array}{l}\text { Further improvement, able to wa्k } \\
3 \text { miles }\end{array}$ \\
\hline 4. & $\begin{array}{l}\text { Leg }+ \\
\text { Hand }++\end{array}$ & $\overline{t+}$ & $98 \pm 22$ & $\begin{array}{l}606 \pm 190 \\
\text { Improved }\end{array}$ & None & YES & 6 & Further improvement \\
\hline 5. & +++ & + & $8 \pm 2$ & $\underset{\text { Improved }}{24 \pm} 6$ & None & NO & 1 week & Died of ruptured aortic aneurysig \\
\hline 6. & - & - & $50 \pm 11$ & $\begin{array}{l}83 \pm 6 \\
\text { Improved }\end{array}$ & None & $\begin{array}{l}\text { NOT } \\
\text { YET }\end{array}$ & 2 & Improvement continues \\
\hline 7. & +++ & ++ & $13 \pm 15$ & $\begin{array}{l}12 \pm 8 \\
\text { No change }\end{array}$ & $\begin{array}{l}\text { Temporary improvement of } \\
\text { colour of foot }\end{array}$ & NO & 9 & Left below knee amputation \\
\hline 8. & + & + & $133 \pm 35$ & $142 \pm 12$ & None & NO & 9 & Claudication. Indolent ulcer \\
\hline 9. & - & - & $100 \pm 20$ & $\begin{array}{l}126 \pm 25 \\
\text { No change }\end{array}$ & None & NO & 1 & No change సิ \\
\hline 10. & +++ & +++ & $55 \pm 7$ & $\begin{array}{l}69 \pm 8 \\
\text { No change }\end{array}$ & None & NO & 1 & Being considered for amputation \\
\hline
\end{tabular}


Of three patients with indolent ulcers, one healed within a fortnight of stimulation and one was not improved. The third patient (case 5) who had had remarkable relief from rest pain during the period of spinal cord stimulation died of a ruptured aortic aneurysm one week after starting. The duration of his stimulation was too short to allow for healing of ulcers. In four out of seven patients with striking discolouration of the feet, there was an improvement in colour though in one this was only temporary. One patient reported restoration of sweating in the feet. In four out of the ten patients there was a very striking increase in the claudication distance. In two others there was a moderate but significant increase in claudication distance which, in one of these patients, was sufficient to enable him to go shopping with his wife, for the first time for years. In four patients there was no significant change in claudication distance. In one of these patients, although there was no reduction in claudication distance, rest pain and dependent rubor became worse. The mean pre-stimulation claudication distance was $65 \pm 45$ metres and that during spinal cord stimulation was $212 \pm 147$ metres. This difference was significant $(0.025>p>0 \cdot 01)$.

\section{CLINICAL RESPONSE TO TRANSCUTANEOUS}

STIMULATION

Seven patients received transcutaneous stimulation before going on to epidural stimulation of the spinal cord. None of these patients showed any clinical improvement during a two week period of transcutaneous stimulation. Assessment of their claudication distance and exercise tolerance on the bicycle ergometer showed no change from the prestimulation state.

\section{EXERCISE ENDURANCE ON THE BICYCLE \\ ERGOMETER}

Exercise tolerance increased from $3929 \pm 1961$ joules to $6328 \pm 3421$ joules $(61 \%$ increase) but this was not statistically significant $(0 \cdot 10>p>$ $0 \cdot 05)$.

BLOOD FLOW STUDIES (tables 3 and 4)

Skin blood flow was measured in eight out of the 10 patients who responded clinically. Skin blood flow measurements were made at two sites on each leg. For a variety of reasons blood flow studies on the right legs are incomplete and only the results for the left legs and feet are given. There was a significant

Table 3 Effect of spinal cord stimulation (SCS) on blood flow in peripheral vascular disease

Patients responding

Mean and standard deviation given

\begin{tabular}{|c|c|c|c|c|c|}
\hline Test & Units & $n$ & Before & $S C S$ & $p^{*}$ \\
\hline $\begin{array}{l}\text { Skin blood flow: } \\
\text { Left foot }\end{array}$ & $\mathrm{ml} / \mathrm{min} / 100 \mathrm{G}$ & 4 & \multirow{2}{*}{$\begin{array}{r}5.45 \\
\pm 1.13 \\
3.33 \\
\pm 1.86\end{array}$} & \multirow{2}{*}{$\begin{array}{r}6.90 \\
+1.64 \\
3.23 \\
+0.70\end{array}$} & 0.02 \\
\hline Left leg & $\mathrm{ml} / \mathrm{min} / 100 \mathrm{G}$ & 4 & & & NS \\
\hline $\begin{array}{l}\text { Muscle blood flow: } \\
\text { Rest }\end{array}$ & $\mathrm{ml} / \mathrm{min} / 100 \mathrm{G}$ & 4 & \multirow{2}{*}{$\begin{array}{r}1.10 \\
\pm 0.68 \\
3.68 \\
\pm 1.45\end{array}$} & \multirow{2}{*}{$\begin{array}{r}2.20 \\
\pm 1.13 \\
5.24 \\
+2.93\end{array}$} & 0.05 \\
\hline Exercise & $\mathrm{ml} / \mathrm{min} / 100 \mathrm{G}$ & 4 & & & NS \\
\hline
\end{tabular}

${ }^{*}$ p calculated by paired $t$ test

Table 4 Effect of spinal cord stimulation (SCS) on blood flow in peripheral vascular disease Non-responders

Mean and standard deviation given

\begin{tabular}{|c|c|c|c|c|c|}
\hline Test & Units & $n$ & Before & $S C S$ & $p^{*}$ \\
\hline $\begin{array}{l}\text { Skin blood flow: } \\
\text { Left foot }\end{array}$ & $\mathrm{ml} / \mathrm{min} / 100 \mathrm{G}$ & 4 & $\begin{array}{r}2.40 \\
+3.50\end{array}$ & $\begin{array}{r}1.68 \\
+1.71\end{array}$ & NS \\
\hline Left Leg & $\mathrm{ml} / \mathrm{min} / 100 \mathrm{G}$ & 4 & $\begin{array}{r}1.33 \\
\pm 0.40\end{array}$ & $\begin{array}{r}1.38 \\
\pm 1.31\end{array}$ & NS \\
\hline $\begin{array}{l}\text { Muscle blood flow: } \\
\text { Rest } \\
\text { Exercise }\end{array}$ & $\begin{array}{l}\mathrm{ml} / \mathrm{min} / 100 \mathrm{G} \\
\mathrm{ml} / \mathrm{min} / 100 \mathrm{G}\end{array}$ & 1 & $\begin{array}{l}1 \cdot 2 \\
\text { Not done }\end{array}$ & $1 \cdot 2$ & NS \\
\hline
\end{tabular}

${ }^{*}$ p calculated by paired $t$ test 
increase in blood flow in the left foot of the clinically responding patients but not at the site on the left legs just below the head of the fibula. The nonresponders showed no significant change in blood flow.

Muscle blood flow at rest and during exercise was measured in four of the responding patients but only incomplete studies in one of the non-responders are available. Of the responding patients there was a statistically significant doubling of muscle blood flow at rest. During exercise an increase in blood flow was recorded but this did not reach statistical significance. Only one non-responding patient was studied and showed no change at rest.

In summary, those patients who had a favourable clinical response also showed an improvement in four of the six objective tests of exercise tolerance and blood flow, while of the patients who did not respond clinically there were no changes in the assessment tests with the exception of the bicycle ergometer test where there was a slight deterioration in performance. We conclude that the clinical improvement seen in these patients cannot be attributed to a placebo response but it is probable that some beneficial physiological change occurred in the peripheral vascular system.

\section{Discussion}

The patients selected for spinal cord stimulation all had severe symptoms and had either failed to respond to conventional surgical and medical treatment or were unsuitable for such treatment. Five out of ten patients had a sufficiently marked clinical response to justify permanent stimulation. A sixth patient had had a good response but died suddenly of a ruptured aortic aneurysm in the epidural stimulation period. It was possible to demonstrate moderate increases in skin and/or muscle blood flow and these were statistically significant in the skin of the foot and in the case of resting muscle blood flow. Muscle blood flow during exercise showed an increase which did not reach statistical significance.

In all patients the improvements obtained initially were maintained as long as permanent stimulation could be continued. In two of the patients receiving permanent stimulation, spinal cord stimulation had to be discontinued for technical reasons and both deteriorated clinically. Repair of the spinal cord stimulation system so that a stimulator sensation was once more obtained in the legs at once restored the improvement that had been obtained. In one patient receiving permanent stimulation, who had developed gangrene in the hand, an area not being stimulated at the time, insertion of electrodes to produce a stimulator sensation in the hand did not reverse the gangrene. This experience is consistent with Cook's observation ${ }^{8}$ that once gangrene has set in, spinal cord stimulation has little to offer.

In interpreting the response to a new form of treatment one must take into account the natural history of the disease and the possibility of placebo effect. It is well known that intermittent claudication tends to improve with time ${ }^{1718}$ but this usually occurs over a period of months rather than days, and moreover tends to occur in the early stages of the illness. It is usual for patients with severe persistent rest pain to remain stable or to get worse.

Transcutaneous stimulation might reasonably have been expected to produce similar symptomatic relief if the patients were responding to a placebo effect. Both spinal cord stimulation and transcutaneous stimulation techniques involved electrodes, wires and stimulator controls and both produced a sensation. Care was taken to ensure that the patients could not infer which method was supposed to work. Measurement of current in the epidural space during transcutaneous stimulation showed it to be less than with spinal cord stimulation by a factor of 2,000. It would therefore appear impossible to stimulate the spinal cord by transcutaneous stimulation using the currents and voltages available. No symptomatic or objectively measured improvement occurred with transcutaneous stimulation. The duration of the improvement seen and its dependency upon continuing spinal cord stimulation is against a placebo effect. The improvements noted in blood flow and the other objectively measured changes make a placebo effect less likely.

Our findings with transcutaneous stimulation are contrary to those of Canosa et al ${ }^{19}$ who reported improvement in patients with peripheral vascular disease during transcutaneous stimulation over a three month period..

MECHANISMS

Several mechanisms may be invoked to account for the improvements seen:

1. Pain relief: Pain relief, a well documented effect of spinal cord stimulation, may release the reflex vasoconstriction that is known to occur in response to pain. This might break a vicious circle by which pain leads to vasoconstriction and vasoconstriction leads to further pain.

2. Sympathetic nervous system: Very small changes in blood flow may be critical in determining whether skin is viable and also in influencing claudication distance. The xenon clearance method of blood flow measurement has well known sources of error and variation and must, at best, be considered a rather insensitive measure of detecting clinically significant alterations in circulation. However, a statistically 
significant increase in muscle blood flow and in skin blood flow of the foot, but not of the lower leg, was detected in response to spinal cord stimulation. If the clinical improvement is due to increased blood flow, as well as to pain control, then it seems unlikely that the sympathetic nervous system should be involved. Whereas inhibition of alpha adrenergic vasconstrictor fibres and stimulation of cholinergic vasodilator fibres will produce respectively increased blood flow in the skin and in the muscles, it is unlikely that spinal cord stimulation will produce this balanced combination of effects.

3. Prostaglandins and prostacyclins: Bayliss $^{20}$ demonstrated that stimulation of the dorsal roots produced hind limb vasodilatation in the cat and Foerster $^{21}$ showed that dorsal root stimulation in man produced vasodilatation in the appropriate dermatome. Recently Hilton and Marshall ${ }^{22}$ have demonstrated vasodilatation in the muscles following dorsal root stimulation and they believe that this effect is due to antidromic stimulation of small diameter fibres. Interestingly, it could not be blocked by sympathetic blocking agents but could be blocked by prostaglandin inhibitors from which they inferred that is was mediated by the release of prostaglandins in muscles. Whether these fibres are involved in the effects seen in ischaemic patients receiving spinal cord stimulation is not certain. There is no doubt, however, that spinal cord stimulation involves stimulation of the central processes of the first order sensory neurons and that there is no reason why these should not be stimulated antidromically as well as orthodromically.

4. Local vascular control: There may be some difficulty in understanding how neural modulation could overcome the essentially structural problem that occurs in obliterative arterial disease. There is, however, some evidence that physiological responses to arterial insufficiency may not be optimal. As noted above, reflex vasoconstriction occurs in response to pain and structural changes in the arterial wall may cause augmentation of vasoconstrictor responses to adrenergic stimuli. ${ }^{23}$ The intraarterial infusion of alpha-adrenergic blockers such as thymoxamine may produce marked improvement in the pulse plethysmograph in patients with severe peripheral vascular disease. ${ }^{24}$ Recently it has been shown that intra-arterial prostacyclin infusion may produce dramatic increases in blood flow associated with marked clinical improvement. ${ }^{25}$ This effect has been attributed to reduction in platelet coagulation, vasodilatation and in some cases the induction of the proliferation of small vessels. At the very least, it does indicate that even in obstructive arterial disease there is a residual neuropharmacological reserve that may be exploited. It is possible that neurally mediated release of prostacyclins resulting from antidromic stimulation of sensory neurons could produce this effect.

It has been argued that a generalised vasodilatation would have an adverse effect on patients with severe arterial disease, increased blood flow being directed towards unobstructed arteries so that blood flow distal to the site of obstruction falls even further. If, however, the ony effect of spinal cord stimulation is to reverse adverse physiological changes that occur locally distal to the site of a block, then of course vasodilatation would occur only in those places where it was required and not elsewhere where it may lead to further diminution of blood flow in ischaemic areas.

This work is still at a very early stage. The results that we have obtained so far, both in terms of clinical response and objective measures of claudication and exercise tolerance, as well as some of the changes seen in blood flow, suggest that spinal cord stimulation may have a part to play in the management of advanced arterial disease where all other forms of treatment have failed. Clearly this will represent only a small group of patients and this group will be even smaller if sufferers from vascular disease were able to resist the urge to smoke. ${ }^{26}$ Moreover, spinal cord stimulation will have no influence upon the underlying pathology and cannot be expected to reverse gangrene. In view of the encouraging results a larger trial is underway in order to clarify the indications for spinal cord stimulation and to investigate the mechanisms involved.

We are very grateful to Mr J Webster, FRCS and Mr AD Chant, FRCS of the Department of Vascular Surgery at the Royal South Hampshire Hospital for kindly referring patients. We are also grateful to Mr CAC Clyne for useful advice at many stages of the present project. Finally, we thank Miss Gillian Green for typing the manuscript.

\section{References}

${ }^{1}$ Shealy CN, Mortimer JT, Reswick, JB. Electrical inhibition of pain by stimulation of the dorsal columns: preliminary clinical report. Anesth. Analg. (Cleve) 1967;46:489-91.

${ }^{2}$ Cook AW, Weinstein SP. Chronic dorsal column stimulation in multiple sclerosis: preliminary report. $N T$ State J Med 1973;73:2868-72.

${ }^{3}$ Shimoji K, Kitamura $H$, Hezono E, Shimizu $H$, Okamoto K, Iwakura Y. Spinal hypalgesia and analgesia by low frequency electrical stimulation in the epidural space. Anesthesiology 1974;41:91-4.

${ }^{4}$ Illis LS, Sedgwick EM, Tallis RC. Spinal cord stimulation in multiple sclerosis: clinical results. $J$ Neurol Neurosurg Psychiatry 1980;43:1-14. 
${ }^{5}$ Hawkes CH, Wyke MA, Desmond A, Bultitude MI, Kanegaonkar GS. Stimulation of the dorsal column in multiple sclerosis. Br Med J 1980;1:889-91.

- Read DJ, Matthews WB, Higson RH. The effect of spinal cord stimulation on function in patients with multiple sclerosis. Brain 1980;103:803-33.

${ }^{7}$ Friedman H, Nashold BS, Somjen G. Physiplogical effects of dorsal column stimulation. Adv Neurol 1974;4:769.

${ }^{8}$ Cook AW, Oygar A, Baggenstos P, Pacheto S, Kleriga E. Vascular disease of the extremities: electrical stimulation of the spinal cord and the posterior roots. NY State J Med 1976;76:366-8.

${ }^{9}$ Owens S, Atkinson ER, Lees DE. Thermographic evidence of reduced sympathetic tone with transcutaneous nerve stimulation. Anesthesiology 1979;50:620-5.

${ }^{10}$ Ebershold MJ, Laws ER, Albers JW. Measurements of autonomic function before, during and after TNS in patients with chronic pain and control subjects. Mayo Clin Proc 1977;52:228-32.

11 Abram SE. Increased sympathetic tone associated with transcutaneous electrical stimulation. Anesthesiology 1976;45:575-7.

12 Abram SE, Asiddao CB, Reynolds AC. Increased skin temperature during transcutaneous electrical stimulation. Anesth Analg (Cleve) 1980;59:22-5.

${ }^{13}$ Tallis RC, Illis LS, Sedgwick EM, Hardwidge C, Kennedy $K$. The effect of spinal cord stimulation upon peripheral blood flow in patients with chronic neurological disease. Int Rehabil Med 1983; in press.

${ }^{14}$ Sjersen P. Cutaneous blood flow in man studied by freely diffusable radioactive indicators. Scand J Clin Lab Invest 1966;Suppl 99:52-9.

${ }^{15}$ Cook AW. Electrical stimulation in multiple sclerosis. Hosp Pract 1976;2:51-8.
${ }^{16}$ Jobling DT, Tallis RC, Sedgwick EM, Illis LS. Electronic aspects of spinal cord stimulation in multiple sclerosis. Med Biol Eng Comput 1980;18:48-56.

${ }^{17}$ Hughson WG, Mann JI, Tibbs DJ, Woods HF, Walton I. Intermittent claudication: factors determining outcome. Br Med J 1978;1:1377-81.

${ }^{18}$, Jonason T, Jonzon B, Ringquist I, Oman-Rydberg A. Effect of physical training on different categories of patients with intermittent claudication. Acta Med Scand 1979;206:253-8.

${ }^{19}$ Canosa F, Dooley DM, Boyle E. Vascular reactions to pre and post transcutaneous electrical stimulation of the spinal cord and nerve roots. In "Proceedings of the Sixth International Symposium on External Control of Human Extremities". Yugoslav Committee for Electronics and Automation, Belgrade. 1978;585-601.

${ }^{20}$ Bayliss W. On the origin from the spinal cord of vasodilator fibres of the hind limb. J Physiol (Lond) 1901;26:173-209.

${ }^{21}$ Foerster $O$. The dermatomes in man. Brain 1933;56:1-38.

22 Hilton SM, Marshall JM. Dorsal root vasodilatation in cat skeletal muscle. J Physiol (Lond) 1980;299:27788.

${ }^{23}$ Folkow B. The haemodynamic consequences of adaptive structural changes of the resistance vessels in hypertension. Clin Sci 1971;41:1-12.

${ }^{24}$ Rose SS. The use and abuse of vasodilator drugs. Vas Dis 1971;4:(2);67-82.

${ }^{25}$ Szczeklic A, Nizankowski R, Shawinski S, Szczeklik J, Gluszko P, Gryglewski RJ. Successful therapy of advanced arteriosclerosis obliterans with prostacyclins. Lancet 1979;1:1111-14.

${ }^{26}$ Jamieson CW, Clyne CAC. The fate of the ischaemic limb. In: Yu PN, Goodwyn JF, eds. Progress in Cardiology 1978;7:219-28. 